\title{
FOOD AND FEEDING HABITS OF COMMON GARDEN BIRDS IN THE SUBURBS OF JHARKHAND, INDIA
}

\author{
Swetaleena Mishra \\ Department of Zoology \\ Kolhan University, Chaibasa, Jharkhand, India
}

\begin{abstract}
The sight of chirping birds all around and their colorful plumage is a pleasure for humans. The birds are varied in their food choices and feeding habits and this study provides an insight to the varied food types and feeding habits of the different species of birds found very commonly in different suburbs and urban regions in India. The study has been performed by very detailed observational work on the commonly found species of garden birds in the suburb and foothills of Gurabandha forest. Majority of these birds were found to be omnivores, mostly insectivores and frugivorous which clearly explains the type of food resources available for these birds in this region. There is enough forest cover and varied flora that provides enough food and shelter to these wide range of avifauna in the foothills. In this study, about twenty-two species of birds have been identified and their food and feeding habits has been studied in details.
\end{abstract}

Keywords - Avifauna, Ecosystem services, Frugivorous, Granivorous, Nestlings

\section{INTRODUCTION}

Birds are the most colorful organisms that have always captured the imaginations of nature lovers. The type of climate and vegetation determine the population of flora and fauna in a given area. The birds perform many services that help in the sustenance of the ecosystem. The avifauna of an ecosystem provides not only beauty but also serve important ecological services as pollinators, predators, seed predators and dispersers and scavengers, to count a few. This study is quintessential in providing knowledge about the foraging behavior of these beautiful and colorful birds that are commonly found in our surroundings and constantly amaze us by their peculiar foraging behavior and skills. The food and feeding habits of the birds vary as they forage on available food resources in the wild. The foraging behavior has a direct impact on the better chances of survival and continuance of a species. Thus, feeding habits implicates on the fitness, survival and better chances of reproduction. The population of common suburb garden birds that are abundantly found near the human surroundings include the crows and ravens, pigeon and doves, poultry, parrots, bulbul, myna, finches and many more. Most of these birds are insectivores and frugivores but interestingly, many birds are also granivores and omnivores.

\section{RELATED WORK}

Previously research was done on "Nesting and parental care in Cinnyris jugularis" and "Ecology of Merops orientalis". The tiny sunbirds and the beautiful Asian green bee-eaters were found to be abundantly spread in the forest clearings and near and around the human surroundings. The sunbirds are actually nectar -feeders while the bee-eaters are insectivorous species. The olive-back sunbirds often fed their young chicks with some caterpillars and insects besides nectar, which suggests to fulfil the protein requirement of their growing chicks. The green bee-eaters are exceptionally skilled flycatchers and as their name suggests, the natural killers of bees. The sunbirds make hanging nest from dry leaves and cobwebs especially that possess a hood at the entrance of the nest while the green bee-eaters nest in colony on ground, in specially made nest-tunnels. Both are monogamous species.

\section{MATERIALS AND METHODS}

3.1- Description of the study area- The area selected for studying the feeding ecology of the common garden birds in the suburb of Gurabandha forest region is a greenery-rich area. The place is less populated and has lush green surroundings all around. As mentioned above, it is a forest region, so greenery, woodlands are common in the region. Besides, small agricultural lands and numerous small canals and a major river, Subarnarekha, flows nearby. Thus, this area is perfect for studying the diversity of flora and fauna and various other ecological studies. The greenery in this place is attributed to the presence of huge wild berry trees, Bael (Aegle marmelos), Banyan (Ficus benghalensis), Mulberry (Morus indica), Sal (Shorea robusta), Teak (Tectona grandis), Mango (Mangifera indica), Jackfruit (Artocarpus heterophyllus), Jamun (Syzygium cumini), Custard apple(Annona reticulata), Guava (Psidium guajava), Tamarind (Tamarindus indica), Drumstick (Moringa oleifera), Palash (Butea monosperma), Indian coral tree (Erythrina variegata), Indian white champa (Plumeria obtusa), Golden Champa (Magnolia champaca), Night- 


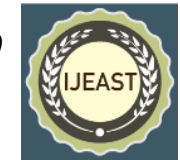

blooming jasmine (Cestrum nocturnum) Neem (Azadirachta indica) and many more wild trees and shrubs. It's a paradise for birds as lots of and varied food resources are available in the wild like fruits, fruit seeds, insects, cereal grains from agricultural lands, worms, insect pests etc. and much more. The study area provides abundant food resources and shelter to diverse avifauna and huge opportunity for their successful survival and reproduction.

3.2- Methodology-The present study of feeding ecology of the common garden birds was done on twenty-two species of birds. First and fore most important aspect of the study was to click the photographs of the birds around the study area and identify the bird species with the help of key books. The photographs of these beautiful birds were clicked using Canon EOS 1200D (Lens-250mm). These colorful species were then identified using key book 'The Birds of India' by Salim Ali. After confirming their identification, their classification was noted down to know more about their traits. Continuous and prolonged observations for 2 hours twice a day was done for over a period of 3 months to derive conclusions on the feeding habits of these identified bird species. The most favorable time for study is the early morning and late afternoon as the birds are most active during these periods. It was ensured that the food and feeding habits of these birds were noted during each observation period. Though, during every observation period all the species of birds were not seen together, but they move in their own territory and can be easily seen there wandering about most of time. As soon as these flying wonders were seen foraging, their feeding ecology was noted down.

\section{RESULTS AND DISCUSSIONS}

4.1- Identification of birds- As mentioned above, the study area has huge diversity of avifauna, it was the priority of the study to identify and classify these wonderful creatures. Thus, about twenty-two species common garden birds in this suburb were identified and further classified for convenience. The food preferences of these identified birds have also been tabulated below.

Table 1. Classification and diet of common garden birds.

\begin{tabular}{|c|c|c|c|}
\hline S/n & $\begin{array}{c}\text { Common } \\
\text { name }\end{array}$ & $\begin{array}{c}\text { Classification } \\
\text { Order/Family } \\
\text { /Genus/Species }\end{array}$ & Food \\
\cline { 3 - 3 } 1 & $\begin{array}{c}\text { Black } \\
\text { drongo }\end{array}$ & $\begin{array}{c}\text { Passeriformes } \\
\text { Dicruridae } \\
\text { Dicrurus macrocercus } \\
\text { (Vieillot, 1817) }\end{array}$ & Insects \\
\hline 2 & $\begin{array}{c}\text { Brahminy } \\
\text { starling }\end{array}$ & $\begin{array}{c}\text { Passeriformes } \\
\text { Sturnidae } \\
\text { Sturnia pagodarum } \\
\text { (Gmelin, 1789) }\end{array}$ & Fruits and insects \\
\hline 3 & $\begin{array}{c}\text { Black- } \\
\text { hooded }\end{array}$ & $\begin{array}{c}\text { Passeriformes } \\
\text { Oriolidae } \\
\text { Oriolus xanthornus } \\
\text { (Linnaeus, 1758) }\end{array}$ & Berries, fruits, \\
nectar, insects
\end{tabular}

\begin{tabular}{|c|c|c|c|}
\hline & & $\begin{array}{c}\text { Corvidae } \\
\text { Corvus splendens } \\
\text { (Vieillot, 1817) }\end{array}$ & $\begin{array}{l}\text { invertebrates and } \\
\text { vertebrates. Act as } \\
\text { scavengers. }\end{array}$ \\
\hline 5 & Cock & $\begin{array}{c}\text { Galliformes } \\
\text { Phasianidae } \\
\text { Gallus gallus } \\
\text { (Linnaeus, 1758) } \\
\end{array}$ & $\begin{array}{l}\text { Seeds, grains, } \\
\text { insects, fruits }\end{array}$ \\
\hline 6 & Coucal & $\begin{array}{l}\text { Cuculiformes } \\
\text { Cuculidae } \\
\text { Centropus sinensis } \\
\text { (Stephens, 1815) }\end{array}$ & $\begin{array}{l}\text { Fruits, seeds, } \\
\text { insects, worms, } \\
\text { small vertebrates. }\end{array}$ \\
\hline 7 & Cuckoo & $\begin{array}{l}\text { Cuculiformes } \\
\text { Cuculidae } \\
\text { Cuculus canorus } \\
\text { (Linnaeus, 1758) }\end{array}$ & $\begin{array}{l}\text { Insects, caterpillars, } \\
\text { fruits. }\end{array}$ \\
\hline 8 & $\begin{array}{c}\text { Green } \\
\text { bee-eater }\end{array}$ & $\begin{array}{l}\text { Coraciformes } \\
\text { Meropidae } \\
\text { Merops orientalis } \\
\text { (Latham, 1801) } \\
\end{array}$ & Bees, Insects. \\
\hline 9 & Hariyal & $\begin{array}{c}\text { Columbiformes } \\
\text { Columbidae } \\
\text { Treron phoenicoptera } \\
\text { (Latham, 1790) }\end{array}$ & $\begin{array}{c}\text { Berries, fruits, } \\
\text { seeds, grains }\end{array}$ \\
\hline 10 & $\begin{array}{l}\text { Magpie } \\
\text { Robin }\end{array}$ & $\begin{array}{c}\text { Passeriformes } \\
\text { Muscicapidae } \\
\text { Copsychus saularis } \\
\text { (Linnaeus, 1758) }\end{array}$ & $\begin{array}{l}\text { Insects, small } \\
\text { invertebrates. }\end{array}$ \\
\hline 11 & Myna & $\begin{array}{c}\text { Passeriformes } \\
\text { Sturnidae } \\
\text { Acridotheres tristis } \\
\text { (Linnaeus, 1766) } \\
\end{array}$ & $\begin{array}{c}\text { Seeds, fruits, grains, } \\
\text { insects, small } \\
\text { invertebrates and } \\
\text { vertebrates. } \\
\end{array}$ \\
\hline 12 & $\begin{array}{l}\text { Olive- } \\
\text { back } \\
\text { sunbird }\end{array}$ & $\begin{array}{c}\text { Passeriformes } \\
\text { Nectariniidae } \\
\text { Cinnyris jugularis } \\
\text { (Linnaeus, 1766) }\end{array}$ & $\begin{array}{l}\text { Nectar, insects for } \\
\text { feeding chicks }\end{array}$ \\
\hline 13 & Parrot & $\begin{array}{c}\text { Psittaciformes } \\
\text { Psittaculidae } \\
\text { Psittacula krameria } \\
\text { (Scopoli, 1769) } \\
\end{array}$ & $\begin{array}{c}\text { Seeds, berries, } \\
\text { fruits, corns, } \\
\text { vegetable buds, } \\
\text { grains. } \\
\end{array}$ \\
\hline 14 & Pigeon & $\begin{array}{l}\text { Columbiformes } \\
\text { Columbidae } \\
\text { Columba livia } \\
\text { (Gmelin, 1789) } \\
\end{array}$ & Seeds, grains, nuts. \\
\hline 15 & $\begin{array}{l}\text { Red- } \\
\text { vented } \\
\text { bulbul }\end{array}$ & $\begin{array}{c}\text { Passeriformes } \\
\text { Pycnonotidae } \\
\text { Pycnonotus cafer } \\
\text { (Linnaeus, 1766) }\end{array}$ & $\begin{array}{l}\text { Flowers, fruits, } \\
\text { nectar, small } \\
\text { insects. }\end{array}$ \\
\hline 16 & Raven & $\begin{array}{c}\text { Passeriformes } \\
\text { Corvidae } \\
\text { Corvus corax } \\
\text { (Linnaeus, 1758) }\end{array}$ & $\begin{array}{l}\text { Grains, fruits, } \\
\text { berries, small } \\
\text { vertebrates and } \\
\text { invertebrates. } \\
\text { Scavenge on } \\
\text { carrions. }\end{array}$ \\
\hline 17 & $\begin{array}{l}\text { Rufous } \\
\text { Treepie }\end{array}$ & $\begin{array}{l}\text { Passeriformes } \\
\text { Corvidae } \\
\text { Dendrocitta } \\
\text { vagabunda } \\
\text { (Latham, 1790) }\end{array}$ & $\begin{array}{l}\text { Seeds, fruits, nectar, } \\
\text { insects, small } \\
\text { invertebrates. }\end{array}$ \\
\hline 18 & Sparrow & $\begin{array}{l}\text { Passeriformes } \\
\text { Passeridae }\end{array}$ & $\begin{array}{l}\text { Seeds, cereal grains, } \\
\text { small insects. }\end{array}$ \\
\hline
\end{tabular}


International Journal of Engineering Applied Sciences and Technology, 2020

Vol. 5, Issue 2, ISSN No. 2455-2143, Pages 603-608

Published Online June 2020 in IJEAST (http://www.ijeast.com)

\begin{tabular}{|c|c|c|c|}
\hline & & $\begin{array}{c}\text { Passer domesticus } \\
\text { (Linnaeus, 1758) }\end{array}$ & \\
\hline 19 & $\begin{array}{l}\text { Spice } \\
\text { finch }\end{array}$ & $\begin{array}{c}\text { Passeriformes } \\
\text { Estrildidae } \\
\text { Lonchura punctulate } \\
\text { (Linnaeus, 1758) }\end{array}$ & Seeds, berries. \\
\hline 20 & $\begin{array}{l}\text { Spotted } \\
\text { dove }\end{array}$ & $\begin{array}{c}\text { Columbiformes } \\
\text { Columbidae } \\
\text { Spilopelia chinensis } \\
\text { (Scopoli, 1768) }\end{array}$ & $\begin{array}{l}\text { Grains, seeds, fruits, } \\
\text { berries, insects. }\end{array}$ \\
\hline 21 & $\begin{array}{c}\text { White } \\
\text { Wagtail }\end{array}$ & $\begin{array}{l}\text { Passeriformes } \\
\text { Motacillidae } \\
\text { Motacilla } \\
\text { alba } \\
\text { (Linnaeus,1758) }\end{array}$ & Insects, worms. \\
\hline 22 & $\begin{array}{c}\text { Woodpec } \\
\text { ker }\end{array}$ & $\begin{array}{c}\text { Piciformes } \\
\text { Picidae } \\
\text { Chrysocolaptes } \\
\text { festivus } \\
\text { (Boddaert, 1783) }\end{array}$ & $\begin{array}{l}\text { Insects, ants, } \\
\text { caterpillars. }\end{array}$ \\
\hline
\end{tabular}

From the above tabulation, it can be seen that majority of the garden birds, about 13 species, belong to the Order Passeriformes. The passerines are the small perching birds and are mostly omnivorous. Three species of birds, those identified as pigeons and doves belong to the Order Columbiformes. These birds have short neck and possess a short and slender bill. The cuckoos and coucals are classified in the Order Cuculiformes. These medium-sized songbirds are characteristically brood-parasites and omnivorous.

\section{2- Food and feeding habits of the identified birds}

- Olive-backed Sunbirds-Amongst the identified garden birds in the study, the olive-back sunbirds were found to be exclusively feeding on the nectar from the bright-colored garden flowers like Hibiscus, Palash, Indian- coral tree and Champa ( $P$. obtusa). But they feed on worms and caterpillars to their chicks, probably to meet their high protein requirements during their growth period.

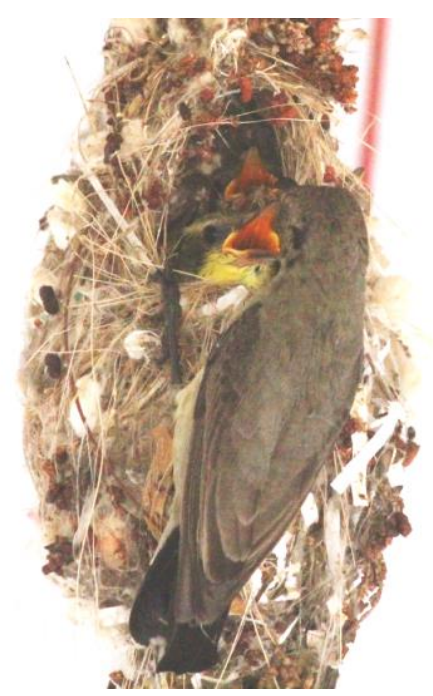

Fig.1. Olive-backed sunbird
- Sparrows-The sparrows are granivorous and feed mostly on cereal grains, seeds, weeds and less often on small insects. The insect diet mostly includes caterpillars and dipteran flies. These small birds are also found to feed on the food provided to them by humans like rice grains, bread crumbs and fruits like berries.

-Pigeons and Doves- The main diet of the pigeons and doves are seeds, grains and fruits. The rock pigeons and doves specifically forage on grains and seeds, being particularly granivorous. But they also feed on small insects and worms found in the soil. The 'Hariyals' (Treron phoenicoptera) or 'yellow-footed green pigeons' as they are commonly called, are mainly frugivorous. They mostly feed on the fruits of the Banyan tree, on which they remain in flocks and forage, as clearly seen in the picture. They also feed on the mulberries, Jamun (Syzygium cumini)), Custard apple (Annona reticulata) and Guava (Psidium guajava).

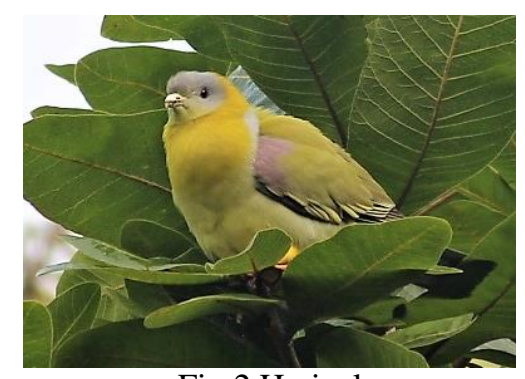

Fig.2 Hariyal

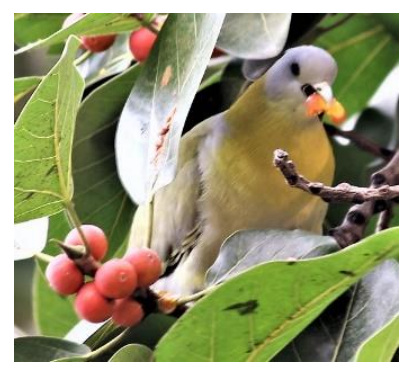

Fig. 3 Hariyal feeding on berries of $F$. banghalensis

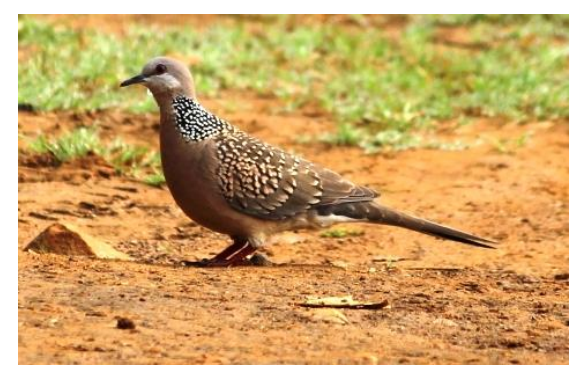

Fig.4 Spotted Dove

- Parrots and Cocks-The parrots and cocks feed on grains, fruits, buds of vegetables, seeds and they cause huge damage to the farm lands nearby. The parrots were also seen feeding 
on the guava fruit, mulberries and the fruits of the Banyan tree. The cocks and hens feed more on the cereal grains and seeds from the garden and more often on the worms found on the ground and egg shells.

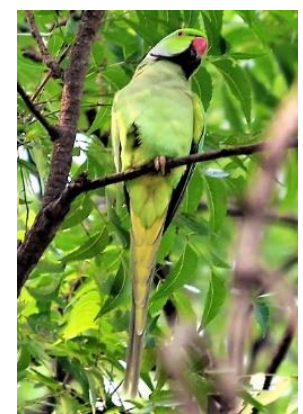

Fig.5 Rose-ringed Parrot

-Black Drongo and Myna-The black drongo and myna were found to be very aggressive birds. They aggressively driveaway other species of birds for food resources. These birds fly very fast and forage on insects like dragonflies, grasshoppers, moths and butterflies and small invertebrates like ants, termites and small worms present in the soil. These are very opportunistic birds and often feed on the eggs and nestlings of other birds. Few instances have been observed where the black Drongo were seen feeding on the nectar of the bright-orange flowers of the Indian coral tree. These two birds have been found to be very compatible with each other, most probably due to their similar feeding habits.

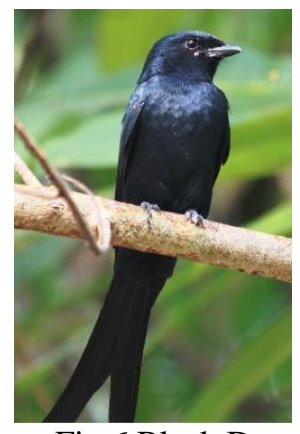

Fig.6 Black Drongo Fig.6 Common Myna
- Green bee-eater-The green bee-eaters and black drongo are skilled acrobats in catching the flying insects. They fly mostly low near the ground in a zig-zag manner and show acrobatic movements to catch their flying prey. The bee-eaters characteristically smack the bees on branches of trees with their bills to destroy their poisonous stings before swallowing them.

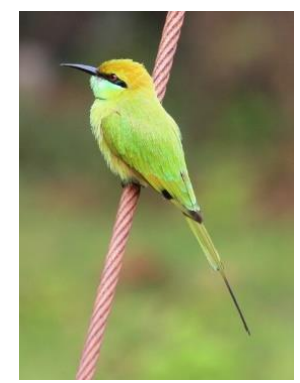

Fig.7 Asian Gree Bee-eater

- Crows and Ravens-The crows and ravens possess very strong claws and beaks that is the characteristic feature of any scavenger. These commonly found birds are omnivores and extensively feed on the carrions, thus cleansing the surroundings. Though considered to be not very attractive and noisy, these aves perform very significant ecological function of keeping the surrounding clean from dead and decaying animals that produce foul smell and may spread diseases.

- Cuckoo - The Asian koel, cuckoo, show a marked sexual dimorphism. The male cuckoo is bluish-black in color and the female is dull greyish or brownish in color and has spotted plumage while their belly side shows stripes. The koels are "brood parasites". They lay their eggs in the nest of crows, ravens, black drongo and mynas. Their young ones are raised by their foster parents. These birds are generally omnivores but mostly feed on fruits and berries available in the wild. These birds are mostly seen in pairs on the higher branches of mango and banyan trees. They also feed on the poisonous fruits of yellow oleander flowers (Cascabela thevetia). Besides, they also feed on small invertebrates. The male species produces a sweet 'koo-ooo' sound repeatedly, mostly during breeding season.

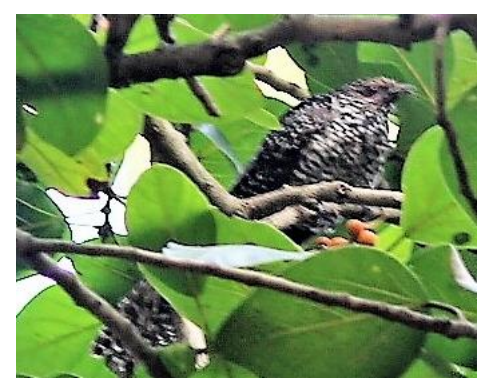

Fig.8 Asiatic Female Cuckoo

- Coucals-The coucals also belong to the family of cuckoos, but they are not brood-parasites like cuckoos. These large birds feed on variety of insects, caterpillars, larvae and small vertebrates. These bird species have adapted to survive near human habitation very successfully, probably due to their omnivorous feeding habits. As these birds are very largesized, it would have been difficult for them to survive near human settlings if they would have been selective in their food habits. 
International Journal of Engineering Applied Sciences and Technology, 2020

Vol. 5, Issue 2, ISSN No. 2455-2143, Pages 603-608

Published Online June 2020 in IJEAST (http://www.ijeast.com)

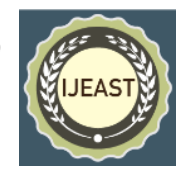

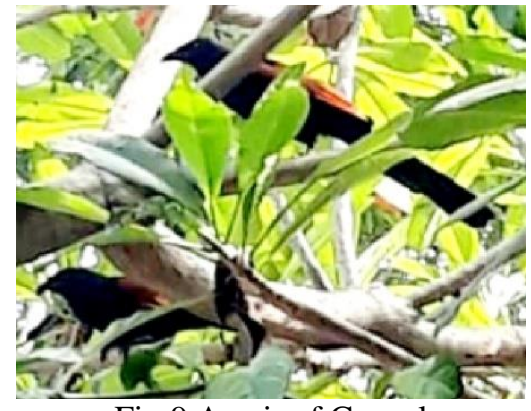

Fig.9 A pair of Coucal

-Spice finch, Black-hooded Oriole, Brahminy Starling, Rufous Treepie, Red-vented bulbul- The spice finches are small sparrow-like birds, commonly called as "munia". These spotted species are always seen in small flocks. These birds forage in flocks on seeds of grass which is their main food. These birds feed on the small flying insects.

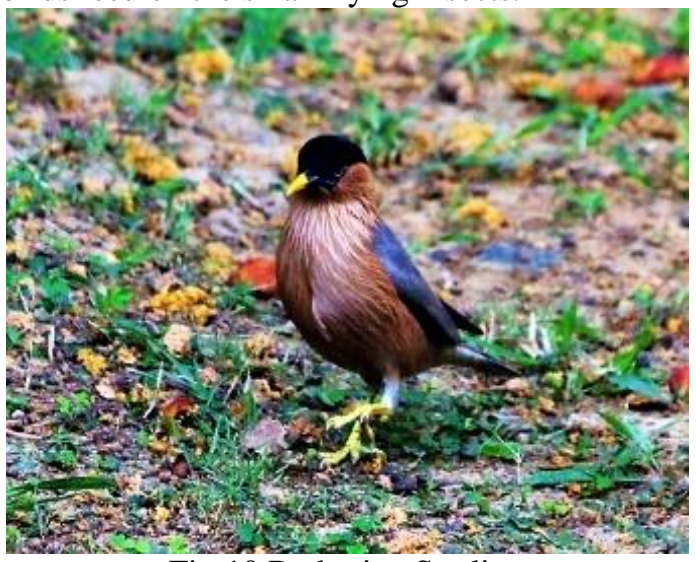

Fig.10 Brahminy Starling

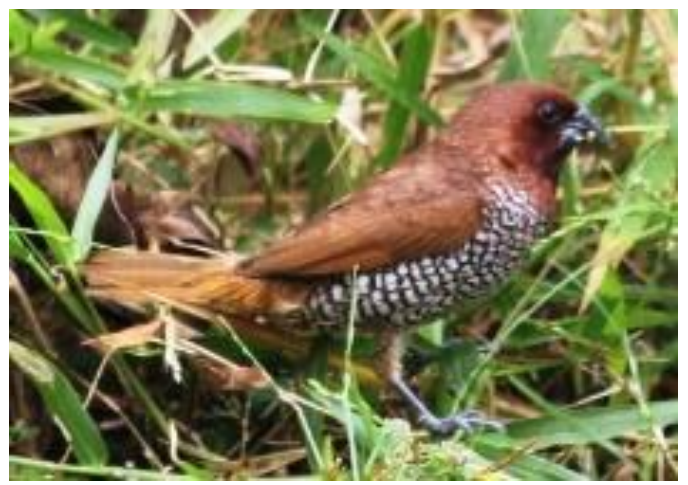

Fig.11 Scaly-breasted Spice finch

The Brahminy starlings, parakeets, spice finches, blackhooded orioles, rufous treepies and red-vented bulbuls feed on the red or bright-orange coloured fruits of the evergreen and fragrant golden Champa (M. champaca) flowers, Mulberries, Banyan trees. The red-vented bulbuls, Brahminy starlings and spice finches were many times seen to feed on the buds and flowers of the night-blooming jasmine plant and Moringa. The
Rufous Treepies were observed to feed on nectar and the other insects residing from the abandoned comb of honey bees (as seen in the fig.12). This amazing species has been found to be very compatible with the Black Drongos. The Rufous treepies also forage on small invertebrates and even on the nestlings of other birds like the Drongos and Crows. They were even sometimes seen feeding on carrions, thus, scavenging like corvids.

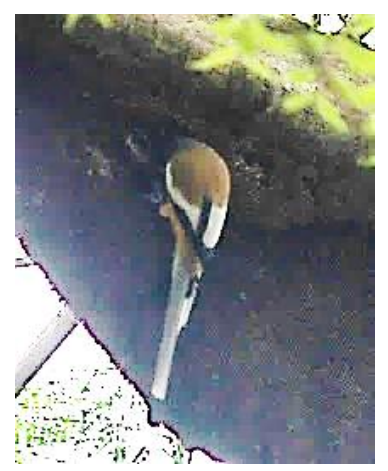

Fig.12 Rufous Treepie feeding nectar and insects from honeycomb

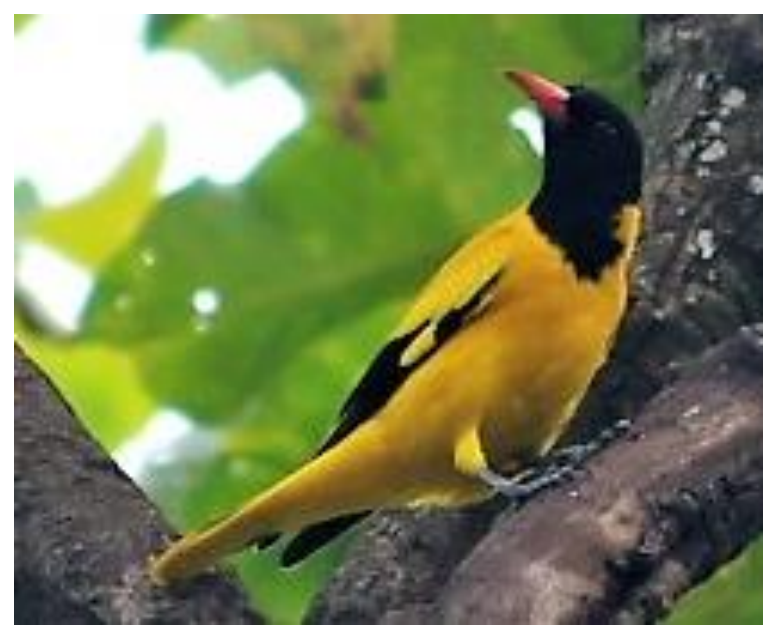

Fig.13 Black-hooded Oriole

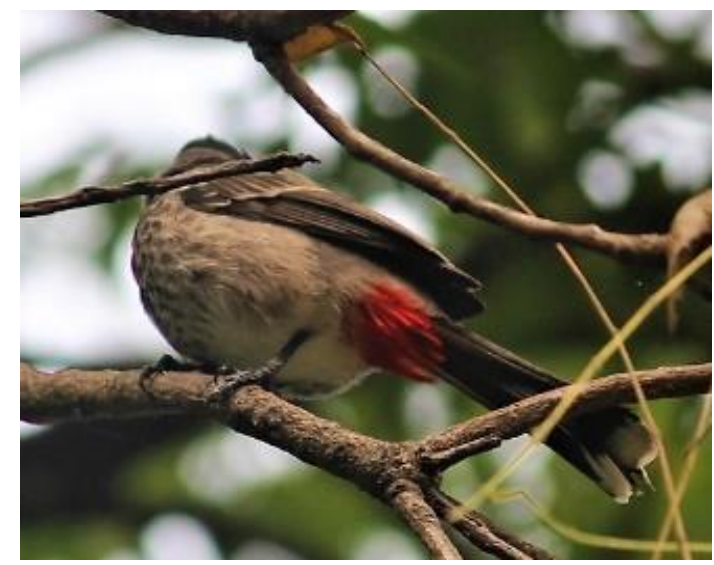

Fig.14 Red-vented Bulbul 


\section{International Journal of Engineering Applied Sciences and Technology, 2020 \\ Vol. 5, Issue 2, ISSN No. 2455-2143, Pages 603-608 \\ Published Online June 2020 in IJEAST (http://www.ijeast.com)}

The starlings, sunbirds, orioles, bulbuls and rufous treepies were found to forage fondly on nectar from the brightlycoloured flowers of Hibiscus, Palash, Karabi (Cascabela thevetia), Indian coral tree, Gulmohar or May-flower tree (Delonix regia) and extremely fragrant flowers of Golden champa (Magnolia champaca) and the Night- blooming jasmine or raat ki rani (Cestrum nocturnum).

-Woodpeckers-The woodpecker is another beautiful as well as a noisy bird. These birds make reverberating sounds and were often found on the higher branches or trunks of huge trees like Neem (A. indica), Gulmohar (D. regia), Golden Champa (M. champaca), Banyan and Jamun trees where they excavate holes to nest and roost. The woodpeckers were found to be solitary species and extensively fed on the small insects like ants, termites and larvae of other insects, fruits and sap from these trees.

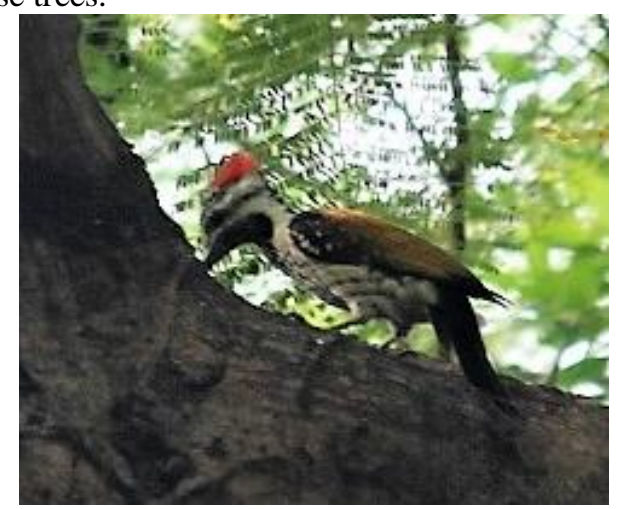

Fig.15 FlamebackWoodpecker

-Wagtails and Magpie Robins-The Wagtails and Magpie robins are very efficient flycatchers and fly very fast with quick strokes of their wings. The Wagtails have a very slender body that helps it in flying in a unique zig-zag manner while catching prey. These beautiful birds with different patterns of black and white colored plumage feed on crickets, grasshoppers, dragon flies, caterpillars, worms etc. The Magpie robins and the white Wagtails also make unique territorial calls. Both these species of birds are often seen together suggesting their compatibility with each other may be due to their similar food habits and habitats.

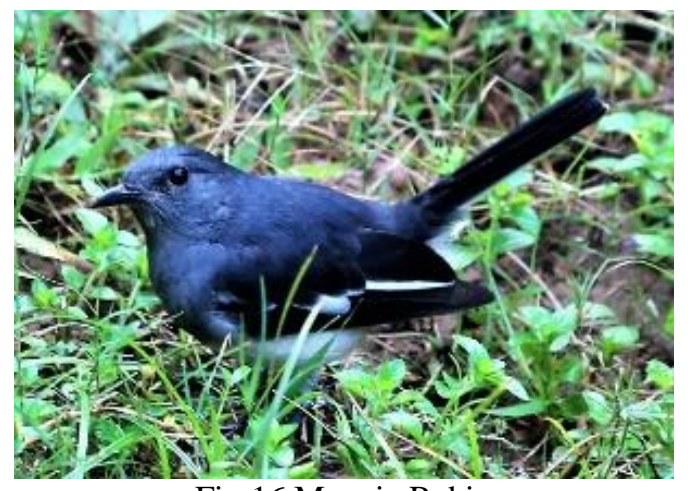

Fig.16 Magpie Robin

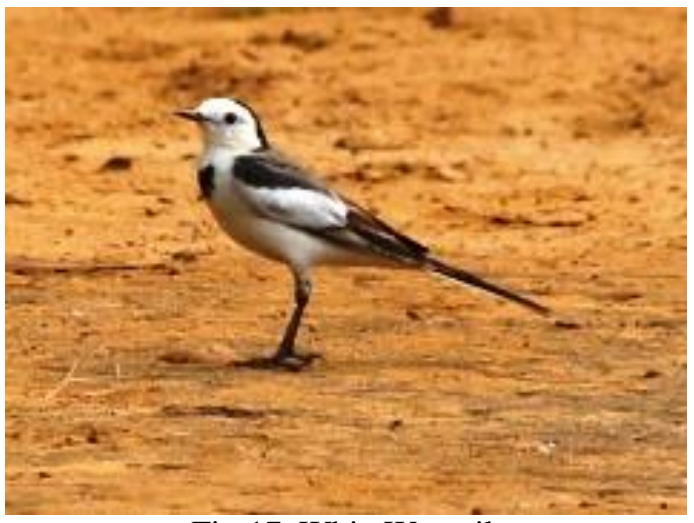

Fig.17 WhiteWagtail

V. CONCLUSION

The twenty-two species of the garden birds that have been identified in this study possess very unique and peculiar traits and show varied food habits as discussed above. The crows, ravens, mynas and parrots are the noisiest birds found in any given surrounding. There is abundance of food resources in this forest region of Gurabandha for the frugivorous species like parrots, hariyals, cuckoos, bulbuls, finches and doves. Hariyals are a type of pigeon-like birds having beautiful light-green plumage with pink collar and typical yellow feet. These birds are native to this region and are extensively frugivorous. But the local tribal people kill them for their meat. This is a painful finding in this study. These lovely birds need to conserved and not killed for flesh. Another interesting finding in this study is the abundance of sparrows in this region as these passerines have become a very rare sight now-a-days due to destruction of their habitats by humans. These different species of birds were observed to be living close to each other and the birds that share common habitats were observed to be possessing similar food and feeding habits. In some cases, like the common Myna often nests in the holes in the branches that were dug by the Woodpeckers. Some studies have suggested that the Mynas and Parrots are considered as invasive species as they drag away the native species. But as mentioned above, there is abundant food resources in this region, so these species of birds, though numerous, have been found to be existing along contentedly with other species. The avifauna identified in this study are all diurnals and are most active during the early morning hours. During the wee hours of the day they most actively forage for their food and this provides them energy after a rest of long night. The birds are considered to be the specialist architect of any ecosystem. They act as pollinators, helping in the blooming of millions of flowers and dispersal of seeds of various fruit-bearing plants which when grow-up form ecological hotspot for diverse species of fauna. They perform a very significant role in the food chains and maintain consistency of any ecosystem. Thus, the birds that are so important components of an ecosystem need to be conserved 


\section{International Journal of Engineering Applied Sciences and Technology, 2020 \\ Vol. 5, Issue 2, ISSN No. 2455-2143, Pages 603-608 \\ Published Online June 2020 in IJEAST (http://www.ijeast.com)}

and their habitats protected for maintaining ecological balance and revival of lost forests and thus, our 'Nature'.

\section{ACKNOWLEDGEMENT}

The author is grateful to the Forest Departments of Jharkhand Government (India), for allowing to venture into the reserve forest area and to the friends of Biology Department, Mosabani Inter College, for helping in collection of photographs and essential data, on the subject.

\section{REFERENCES}

1. Ali. S. and Ripley, S.D. (1999). Handbook of the birds of India and Pakistan. Oxford university Press second ed., Delhi.

2. A. Gil-Tena, Saura. S.and Brotons. L. (2007). Effects of forest composition and structure on bird species richness in a Mediterannian context: implications for forest ecosystem management, Forest ecology and Management, Elsevier 242(2-3), (Pg. 470-476).

3. Biroli, A. P., Grabowska, A., Zhang and Doren. B.M.V. (2020). Drivers of avian species richness and community structure in urban courtyard gardens. Journal of Urban Ecology 6(1).

4. Chaube, R.P., Kumar, A. and Kanaujia, A. (2018). A preliminary study on the birds of a typical sub-urban region of Luckhnow, Uttar Pradesh, India, Journal on New Biological Reports 7(2), (Pg. 81-105).

5. Dookia, S. (2002). A checklist of birds of New Campus, J.N.V. University, Jodhpur, Rajasthan. Zoos' Print Journal 17(9), (Pg. 883-885).

6. Grewal, B., Pfister, O. (2002). A photographic guide to the Birds of the Himalayas, New Holland Publishers (UK) Ltd.

7. Grimmett, R., Inskipp, C. and Inskipp, T. (2007). Pocket Guide to the Birds of the Indian Subcontinent, Oxford University Press.

8. Kasambe, R. and Wadatkar, J.S. (2002). Checklist of birds from Pohara-Malkhed Reserve Forest, District Amravati, Maharastra, Zoos' Print Journal 17(6), (Pg. 807-811).

9. Khera, N., Mehta, V. and Sabata, B.C. (2009). Interrelationship of birds and habitat features in urban greenspaces in Delhi, India, Urban Forestry and Urban Greening 8(3), (Pg. 187-196).

10. Ramesh, M., Nijagunappa, R. and Manjunath, K. (2014). Urbanization impact on avifauna population and its status in Gulbarga city, Karnataka, India, International Letters of Natural Sciences 21.
11. Ramitha, M. and Vijayalaxmi, K.K. (2001). A checklist of birds in and around Mangalore University Campus, Karnateka, Zoos' Print Journal 16(5), (Pg. 489-492).

12. Mishra, S. (2019). The Ecology of Merops orientalis. International Journal of Scientific Research in Biological Sciences 6(5), (Pg. 12-14).

13. Mishra, S. (2019). Nesting and parental care in Cinnyris jugularis. International Journal of Engineering Applied Sciences and Technology4(4), (Pg.119-122).

14. White, J.G., et al. (2005). Non- Uniform Bird Assemblages in Urban Environments: The influence of Streetscape Vegetation, Landscape and Urban Planning 71, (Pg. 123-135). 